\title{
Comparative Study between Dexmedetomidine, Magnesium Sulphate and Meperidine as Anti-Shivering Agent Following Neuraxial Anesthesia
}

\author{
Osama A. Kasem, Mostafa M. El-Sayed, Mahmoud N. Abd Elasttar
}

Department of Anesthesiology and Intensive Care, Faculty of Medicine, Al-Azhar University

Corresponding author: Mahmoud N. Abd Elasttar; Mobile: 01159443114; Email: noorana2020@yahoo.com

\begin{abstract}
Background: shivering is a protective phenomenon which occurs when there is a drop in the core body temperature. As the patients plunge into anesthesia, shivering is always bound to happen, and its avoidance is of prime importance. Aim of the Work: compare the efficacy of intravenous dexmedetomidine $0.5 \mu \mathrm{g} / \mathrm{kg}$ body weight (bw) versus magnesium sulphate $30 \mathrm{mg} / \mathrm{kg}$ bw and meperidine $0.5 \mathrm{mg} / \mathrm{kg}$ bw in the management of shivering in patients undergoing elective surgery under neuraxial anesthesia in Al-Azhar University Hospitals. Patients and Methods: a prospective, double-blinded and controlled randomization study was conducted on 120 ASA grade I and II patients, posted for orthopedic, general surgeries and gynecological surgeries undergoing spinal and combined spinal-epidural anesthesia in Al-Azhar University Hospitals, following approval from the Ethics Committee of the Al-Azhar University. Results: dexmedetomidine was effective in the prevention of shivering throughout a period of 30 minutes. Bradycardia and hypotension were observed in 10 out of 40 patients who received dexmedetomidine and also in 6 out of 40 patients in the magnesium group and with no hypotension and bradycardia in the pethidine group. But of these how many occurred because of dexmedetomidine cannot be commented upon, as spinal and epidural anesthesia itself causes hypotension. Whereas it was observed in 8 out of 40 patients in the magnesium sulfate group. There was no nausea and/or vomiting in pethidine group. These were treated with ondansetron $0.08 \mathrm{mg} / \mathrm{kg}$ by the intravenous route. Conclusion: Dexmedetomidine is an effective drug in the prevention of shivering in patients undergoing neuraxial block.
\end{abstract}

Keywords: Dexmedetomidine, magnesium sulphate, Meperidine, anti-shivering agent, neuraxial anesthesia

\section{INTRODUCTION}

The main temperature in the human body is controlled through the hypothalamus, which regulates the body temperature between 36.5 to $37.5^{\circ} \mathrm{C}$, this is known as the threshold range. It is important for the body to maintain this range of temperature for optimum metabolic and physiological performance and any changes that result in the disruption of these functions ${ }^{(\mathbf{1})}$.

During any form of anesthesia there is an imbalance in the body's ability to generate heat as compared to the heat loss. In general anesthesia use of inhalational anesthetics, inhibition of autonomic system and behavioral responses make the patient suffer from hypothermia, whereas in spinal anesthesia there is a shift of heat to the periphery from the core.This shift occurs because of loss of afferent impulses from the temperature sensing nerve fibers of the lower half of the body as the spinal nerve roots are blocked by the local anesthetic, which is injected into the subarachnoid space $^{(2)}$.

The adverse effects of shivering can lead to increased morbidity. In the process of shivering there is a continuous phase of muscle contractions similar to that of clonus, which leads to anaerobic metabolism, increasing the oxygen consumption and generation of lactate, progressing to metabolic acidosis. This can lead to dangerous consequences in coronary artery diseases, pregnancy and other hemodynamically compromised states. Knowing its dangerous effects many non-pharmacological and pharmacological methods have been tried to overcome and prevent shivering from occurring. Nonpharmacological methods used are insulators, cutaneous warmers placed beneath the patient, covering the exposed areas using blankets, drapes, use of intravenous fluid warmers. Warm air blowers are also used, but they fail to raise the core body temperature. These methods are usually not sufficient and hence pharmacological treatment is almost always clubbed with the above. The drugs used in the treatment of shivering are tramadol, pethidine nefopam, physostigmine, ketamine, ondansetron, and granisetron ${ }^{(3)}$.

Pethidine in the dose of $0.5 \mathrm{mg} / \mathrm{kg}$, but considering its opioid properties of respiratory depression, this drug is being replaced by other newer ones. The availability of pethidine is not hassled free and not every setup can procure this drug ${ }^{(4)}$.

Dexmedetomidine is an $\alpha 2 \mathrm{~A}$ adrenergic receptor agonist. It causes hyperpolarization of the noradrenergic receptors leading to decreased firing from the locus ceruleus. This causes analgesia, sedation and also is the possible mechanism in the prevention of shivering ${ }^{(4)}$.

Intravenous magnesium has been shown to suppress postoperative shivering, suggesting that the agent reduces the shivering threshold. Recently, the addition of intravenous magnesium sulfate to a pharmacological anti-shivering regimen increased the cooling rate in unanesthetized volunteers. The drug not only exerts a central effect, but is also a mild muscle relaxant and may thus simultaneously reduce the gain of shivering (incremental shivering intensity 
with progressing hypothermia). Magnesium also confers substantial neurologic and cardiac protection in several animal models ${ }^{(5)}$.

\section{Aim of the study:}

The purpose of this study was designed to compare the efficacy of intravenous dexmedetomidine $0.5 \mu \mathrm{g} / \mathrm{kg}$ bw versus magnesium sulphate $30 \mathrm{mg} / \mathrm{kg}$ bw and meperidine $0.5 \mathrm{mg} / \mathrm{kg}$ bw in the management of shivering in patients undergoing elective surgery under neuraxial anesthesia in Al-Azhar University hospitals.

\section{Patients and methods}

Ethical approval: This study was a prospective, double-blinded and controlled randomization studied conducted in Al-Azhar University Hospitals, following approval from the Ethics Committee of the Al-Azhar University. Patient informed consent was obtained. A-Patients

120 patients of the following criteria were conducted for this study.

\section{Inclusion criteria}

The study included patients of both genders, aged 18-70 years, with American Society of Anesthesiologists (ASA) physical status I or II, undergoing neuraxial anesthesia (spinal or combined spinal and epidural anesthesia), subjected to elective orthopedic, gynecology or general surgery.

\section{Exclusion criteria}

Patients with a history of convulsions, hypo- or hyperthyroidism, cardiopulmonary disease, renal or liver diseases, psychiatric disorders, neuromuscular pathology, or parkinsonism, Raynaud's syndrome, an allergy to the study drugs, those with an initial heart rate $<50$ beats/minute, systolic blood pressure $<100$ $\mathrm{mmHg}$, body temperature $>38.0^{\circ} \mathrm{C}$ or $<36.0^{\circ} \mathrm{C}$ prior to anesthesia, massive blood transfusion or receiving vasodilator or medication were excluded from the study.

\section{Duration of Study}

January 2018 to December 2018.

\section{B-Methodology:}

Patients complained of shivering were randomly divided into three equal groups according to drugs administered to control shivering:

-Group (D) dexmedetomidine: available as an ampoule (precedex), which contains $200 \mu \mathrm{g} / 2 \mathrm{ml}$. It was manufactured by Pfizer Company. 40 patient received $0.5 \mu \mathrm{g} / \mathrm{kg}$ bw, which was diluted in $20 \mathrm{ml}$ saline over 3-5 min.

-Group (M) magnesium sulfate: available as an ampoule containing $0.5 \mathrm{~g} / 5 \mathrm{ml}$. It was infused as iv bolus of magnesium sulfate $(30 \mathrm{mg} / \mathrm{kg}$ bw) in a total of $100 \mathrm{ml}$ saline over $10 \mathrm{~min}$.

-Group (P) pethidine (40 patients) received $0.5 \mathrm{mg}$ $/ \mathrm{kg}$ bw diluted in $20 \mathrm{ml}$ in over 3-5 min. Pethidine 50 mg was manufactured by Exir Company.
Thus, the study was double-blinded. The temperature of the operating room was maintained at a constant temperature between 22 and 24 degree Celsius (measured by a wall thermometer)

Before performing spinal anesthesia, each patient received $10 \mathrm{ml} / \mathrm{kg}$ bw of lactated Ringer's solution half an hour before spinal anesthesia. Intravenous fluids were administrated at room temperature and given without inline warming. None of the patients were given premedication drugs. Standard monitoring was used throughout the operation. After taking a baseline reading, following the guidelines for asepsis, subarachnoid anesthesia was instituted at the lumbar vertebra $3-4$ or $4-5$ interspaces. $15 \mathrm{mg}$ of hyperbaric bupivacaine was injected using a $23 \mathrm{G}$ spinal needle, with the bevel facing upwards. Supplemental oxygen $(5 \mathrm{l} / \mathrm{min})$ was delivered via a facemask during the operation.

All patients were covered with one layer of surgical drapes over the chest, thighs, and calves during the operation and then one cotton blanket over the entire body. No other warming device was used.

The following parameters were measured for all patients, demographic data: including age, sex, and weight, type and duration of operations; vital signs: when patient was shifted to operation theatre and standard monitors for measurement of heart rate, $\mathrm{SPO}_{2}$, blood pressure, and ECG changes were measured before, and 5, 10 and 15 minutes after treatment administered every 15 minutes and continued up to 3 hours after shivering noticed by Colin monitor. Core temperature: The patient's temperature was recorded at the start of shivering (shivering threshold) and 5, 10, 15 minutes after commencement of treatment of shivering and every 15 minutes and continued up to 3 hours after shivering noticed on the patients, using a tympanic membrane temperature probe. A core temperature below $36^{\circ} \mathrm{C}$ was considered hypothermia . The presence of shivering was assessed by a blinded observer after the completion of subarachnoid drug injection. Shivering was graded with a scale similar to that validated by Crossley and Mahajan: $0=$ No shivering, $1=$ Piloerection or peripheral vasoconstriction but no visible shivering, 2 =Muscular activity in only one muscle group, $3=$ Muscular activity in more than one muscle group but not generalized, $4=$ Shivering involving the whole body. The incidence and severity of shivering were recorded at 15-min intervals during the operation and in the recovery room. Only patients who developed grade 3 or 4 shivering were included in this study. If the score was three or greater one of the three comparative drugs was administered. If the shivering did not cease after 15 minutes, the treatment was regarded as ineffective. Side effects, such as a headache, allergy, hypotension, bradycardia, sedation, nausea and vomiting, pruritus if any were recorded. Bradycardia: If the patient's heart rate fell below 60 bpm, $\quad 0.6 \mathrm{mg}$ atropine was administered i.v. 
Hypotension was defined as a decrease in the mean arterial pressure (MAP) of more than $20 \%$ from baseline. Hypotension was treated with $5 \mathrm{mg}$ (ephedrine) i.v. bolus and then with further i.v. infusion of lactated Ringer's solution as required. If patients developed nausea and vomiting, ondansetron 0.08 $\mathrm{mg} / \mathrm{kg}$ bw was administered through the intravenous route. Sedation score: Richmond agitation score at intervals of 15 minutes, the attending anesthesiologist assessed the degree of sedation on Richmond agitationsedation scale.

\section{Statistical analysis}

Recorded data were analyzed using the statistical package for social sciences, version 20.0 (SPSS Inc., Chicago, Illinois, USA). Quantitative data were expressed as mean \pm standard deviation (SD). Qualitative data were expressed as frequency and percentage.

The following tests were done:
- Independent-samples t-test of significance was used when comparing between two means.

- Chi-square $\left(\mathrm{x}^{2}\right)$ test of significance was used in order to compare proportions between two qualitative parameters.

- The confidence interval was set to $95 \%$ and the margin of error accepted was set to $5 \%$. The p-value was considered significant as the following:

- Probability (P-value)

- P-value <0.05 was considered significant.

- P-value <0.001 was considered as highly significant.

- P-value >0.05 was considered insignificant.

\section{RESULTS}

Demographic data:

Demographic data of the three groups of patients showed no statistically significant differences as regard age, sex, weight, height and ASA state $(\mathrm{P}>0.05)$ as shown in the table (1).

Table (1): Comparison between groups according to demographic data.

\begin{tabular}{|l|l|l|l|l|}
\hline Demographic Data & $\begin{array}{l}\text { Dexmedetomidine } \\
\text { (Group D) N=40 }\end{array}$ & $\begin{array}{l}\text { Magnesium sulfate } \\
\text { (Group M) N=40 }\end{array}$ & $\begin{array}{l}\text { Pethidine } \\
\text { (Group p) N=40 }\end{array}$ & p-value \\
\hline $\begin{array}{l}\text { Age (years) } \\
\text { Range } \\
\text { Mean } \pm \text { SD }\end{array}$ & $18-70$ & $\begin{array}{l}18-70 \\
43.19 \pm 7.34\end{array}$ & $\begin{array}{l}18-70 \\
45.42 \pm 10.45\end{array}$ & 0.157 \\
\hline $\begin{array}{l}\text { Gender } \\
\text { Male }\end{array}$ & $12.53 \pm 9.35$ & $8(30 \%)$ & $10(25 \%)$ & \\
Female & $28(70 \%)$ & $32(80 \%)$ & $30(75 \%)$ & 0.587 \\
\hline Weight $(\mathbf{k g})$ & $70.46 \pm 14.07$ & $63.53 \pm 11.24$ & $65.52 \pm 14.18$ & 0.124 \\
\hline Height $(\mathbf{c m})$ & $166.22 \pm 6.62$ & $166.95 \pm 9.56$ & $165.06 \pm 5.57$ & 0.312 \\
\hline ASA & $24(60 \%)$ & $28(70 \%)$ & $26(65 \%)$ & \\
I & $16(40 \%)$ & $12(30 \%)$ & $14(35 \%)$ & 0.644 \\
\hline II & & & \\
\hline
\end{tabular}

(F-ANOVA test) for Age, Height and Weight, (Chi-square) for Gender and ASA.

\section{The anesthetic approach of neuraxial block and type of operation:}

The Type of neuraxial block in the present study of the three groups of patients showed no statistically significant differences as regard intrathecal or epidural block as shown in the table (2). Also, the type of operation under the neuraxial block showed no statistically significant differences between the three groups in the table (2).

Table (2): Comparison between groups according to anesthetic and surgical data.

\begin{tabular}{|c|c|c|c|c|}
\hline Anesthetic and surgical data & $\begin{array}{l}\text { Dexmedetomidine } \\
\text { (Group D) N=40 }\end{array}$ & $\begin{array}{l}\text { Magnesium } \\
\text { sulfate } \\
\text { (Group M) } \\
\mathbf{N}=\mathbf{4 0}\end{array}$ & $\begin{array}{l}\text { Pethidine } \\
\text { (Group p) } \\
\quad \mathbf{N}=\mathbf{4 0}\end{array}$ & p-value \\
\hline $\begin{array}{l}\text { Types of neuraxial anesthesia } \\
\text { Subarachnoid or spinal } \\
\text { Combined spinal epidural }\end{array}$ & $\begin{array}{l}18(45 \%) \\
22(55 \%)\end{array}$ & $\begin{array}{l}20(50 \%) \\
20(50 \%)\end{array}$ & $\begin{array}{l}20(50 \%) \\
20(50 \%)\end{array}$ & 0.875 \\
\hline $\begin{array}{l}\text { Types of surgery } \\
\text { Orthopedic } \\
\text { General surgery } \\
\text { Gynecological }\end{array}$ & $\begin{array}{l}16(40 \%) \\
12(30 \%) \\
12(30 \%)\end{array}$ & $\begin{array}{l}18(45 \%) \\
10(25 \%) \\
12(30 \%)\end{array}$ & $\begin{array}{l}16(40 \%) \\
14(35 \%) \\
10(25 \%)\end{array}$ & 0.901 \\
\hline
\end{tabular}

By Chi-square test;

\section{Hemodynamics changes after drug were administered:}

Heart rate:

In the current study, there was a significant difference between groups according to heart rate only at 10 and 15 minutes from drug injection (p-value $<0.05)$ as shown in table $(3)$. 
Table (3): Comparison between groups according to heart rate.

\begin{tabular}{|l|l|l|l|l|}
\hline Heart rate & $\begin{array}{l}\text { Dexmedetomidine } \\
\text { (Group D) N=40 }\end{array}$ & $\begin{array}{l}\text { Magnesium sulfate } \\
\text { (Group M) N=40 }\end{array}$ & $\begin{array}{l}\text { Pethidine } \\
\text { (Group p) N=40 }\end{array}$ & P- value \\
\hline Pre-injection & $78.27 \pm 7.70$ & $75.12 \pm 7.22$ & $7.80 \pm 10.97$ & 0.204 \\
\hline $\mathbf{5}$ min & $79.65 \pm 6.487$ & $78.34 \pm 7.914$ & $77.23 \pm 10.864$ & 0.458 \\
\hline $\mathbf{1 0}$ min & $78.27 \pm 7.70$ & $75.540 \pm 7.09$ & $99.3 \pm 0.88^{\mathbf{a b}}$ & $<0.001^{*}$ \\
\hline $\mathbf{1 5}$ & $71.92 \pm 9.998$ & $77.56 \pm 8.972$ & $74.55 \pm 9.761^{\mathbf{b}}$ & $0.033^{*}$ \\
\hline $\mathbf{3 0}$ & $74.12 \pm 8.600$ & $75.12 \pm 7.226$ & $74.46 \pm 9.110$ & 0.861 \\
\hline $\mathbf{4 5}$ & $79.65 \pm 6.487$ & $78.62 \pm 7.801$ & $77.23 \pm 10.864$ & 0.455 \\
\hline $\mathbf{1 h r}$ & $74.12 \pm 8.600$ & $75.40 \pm 7.092$ & $74.05 \pm 8.862$ & 0.714 \\
\hline $\mathbf{3 ~} \mathbf{~ R}$ & $71.18 \pm 11.944$ & $76.90 \pm 10.24^{\mathbf{a}}$ & $74.36 \pm 9.346$ & 0.055 \\
\hline
\end{tabular}

F-ANOVA test;

(a) A significant change between dexmetomidine group and magnesium sulphate group.

(b) A significant change between magnesium sulfate group and pethidine.

(ab) A significant change between dexmedetomidine group and pethidine group.

\section{Mean Arterial Blood pressure}

There was a statistically significant difference between groups according to mean arterial blood pressure only at minute 10 and 15 from drug administration as shown in table (4)

Table (4): Comparison between groups according to mean Arterial blood pressure

\begin{tabular}{|c|c|c|c|c|c|c|}
\hline MAP & \multicolumn{2}{|c|}{$\begin{array}{l}\text { Dexmedetomidine } \\
\text { (Group D) N=40 }\end{array}$} & $\begin{array}{l}\text { Magnesium sulfate } \\
\text { (Group M) N=40 }\end{array}$ & \multicolumn{2}{|c|}{$\begin{array}{l}\text { Pethidine } \\
\text { (Group p) N=40 }\end{array}$} & \multirow{2}{*}{$\begin{array}{l}\text { P- value } \\
0.910\end{array}$} \\
\hline Pre-injection & $75.78 \pm 6$ & & $76.32 \pm 5.993$ & $75.77 \pm$ & 6.800 & \\
\hline $5 \mathrm{~min}$ & $77.10 \pm$ & 7.93 & $76.32 \pm 5.993^{\mathrm{a}}$ & $79.21 \pm$ & 5.352 & 0.130 \\
\hline 10 & $75.35 \pm$ & 9.12 & $80.32 \pm 4.435^{\mathrm{a}}$ & $79.21 \pm$ & $5.352^{\mathrm{ab}}$ & $<0.001 *$ \\
\hline 15 & $75.15 \pm$ & 7.95 & $78.85 \pm 5.008^{a}$ & $79.33 \pm$ & $7.848^{b}$ & $0.017^{*}$ \\
\hline 30 & $77.52 \pm$ & 6.55 & $78.90 \pm 4.974$ & $79.21 \pm$ & 5.352 & 0.373 \\
\hline 45 & $77.10 \pm$ & 7.93 & $76.32 \pm 5.993$ & $77.72 \pm$ & 6.440 & 0.657 \\
\hline $1 \mathrm{hr}$ & $75.78 \pm$ & 6.79 & $76.32 \pm 5.993$ & $75.77 \pm$ & 6.800 & 0.910 \\
\hline $3 \mathrm{hr}$ & $77.52 \pm$ & 6.55 & $78.90 \pm 4.974$ & $77.72 \pm$ & 6.440 & 0.539 \\
\hline
\end{tabular}

F-ANOVA test;

(a) Significant change between dexmetomidine group and magnesium sulphate group.

(b) A significant change between magnesium sulfate group and pethidine.

(ab) A significant change between dexmedetomidine group and pethidine group. Oxygen saturation:

There was no statistically significant difference as regard oxygen saturation between the three groups as shown in the table (5).

Table (5): Comparison between groups according to oxygen saturation.

\begin{tabular}{|l|l|l|l|l|}
\hline & $\begin{array}{l}\text { Dexmedetomidine } \\
\text { (Group D) N=40 }\end{array}$ & $\begin{array}{l}\text { Magnesium sulfate } \\
\text { (Group M) N=40 }\end{array}$ & $\begin{array}{l}\text { Pethidine } \\
\text { (Group p) N=40 }\end{array}$ & P-value \\
\hline 5 min & $98.075 \pm 0.82$ & $98.049 \pm 0.83$ & $98.410 \pm 0.88$ & 0.112 \\
\hline 10 min & $98.45 \pm 0.59$ & $98.46 \pm 0.59$ & $98.15 \pm 0.93$ & 0.103 \\
\hline $\mathbf{1 5}$ & $98.34 \pm 0.73$ & $98.38 \pm 0.83$ & $98.39 \pm 0.80$ & 0.730 \\
\hline $\mathbf{3 0}$ & $98.28 \pm 0.76$ & $98.20 \pm 0.72$ & $98.46 \pm 0.86$ & 0.181 \\
\hline $\mathbf{4 5}$ & $98.30 \pm 0.74$ & $98.25 \pm 0.63$ & $98.39 \pm 0.80$ & 0.633 \\
\hline $\mathbf{1 h r}$ & $98.31 \pm 0.78$ & $98.45 \pm 0.58$ & $98.08 \pm 0.82$ & 0.065 \\
\hline 3 HR & $98.08 \pm 0.82$ & $98.45 \pm 0.56$ & $98.08 \pm 0.87$ & 0.064 \\
\hline
\end{tabular}

F-ANOVA test;

\section{Tympanic temperature:}

There were no statistically significant differences between groups as regard shivering threshold. But after drugs injection there was significant change in temperature between the three groups. In dexmetomidine group there was a significant improving in core temperature as shown in table (6). 
Table (6): Comparison between groups according to temperature

\begin{tabular}{|c|c|c|c|c|}
\hline Temperature $\left(^{\circ}\right)$ & $\begin{array}{l}\text { Dexmedetomidine } \\
\text { (Group D) N=40 }\end{array}$ & \begin{tabular}{|l} 
Magnesium \\
sulfate \\
(Group M) N=40
\end{tabular} & $\begin{array}{l}\text { Pethidine } \\
\text { (Group p) N=40 }\end{array}$ & p-value \\
\hline Shivering threshold & $36.44 \pm 0.18$ & $36.40 \pm 0.18$ & $36.39 \pm 0.18$ & 0.061 \\
\hline After 5 min. & $36.26 \pm 0.15$ & $36.07 \pm 0.14^{\mathrm{a}}$ & $36.17 \pm 0.14^{\mathrm{ab}}$ & $0.013^{*}$ \\
\hline After $10 \mathrm{~min}$. & $36.29 \pm 0.18$ & $36.10 \pm 0.18^{\mathrm{a}}$ & $36.20 \pm 0.18^{\mathrm{ab}}$ & $0.004 *$ \\
\hline After $15 \mathrm{~min}$. & $36.37 \pm 0.13$ & $36.19 \pm 0.09^{\mathrm{a}}$ & $36.29 \pm 0.11^{\mathrm{ab}}$ & $0.002 *$ \\
\hline
\end{tabular}

(a) p-value $>0.05 \mathrm{NS}$; **p-value $<0.001$ Highly significant

(b) a Significant change between dexmedetomidine group and magnesium sulfate group.

(c) A significant change between magnesium sulfate group and pethidine.

(ab) A significant change between dexmedetomidine group and pethidine group.

\section{Shivering grade:}

This table shows the patient ratio subjected to shivering and their grades distributed between the 3 groups (dexmedetomidine - pethidine - magnesium sulfate). There were no statistically significant differences according to shivering grades (Table 7).

Table (7): Comparison between groups according to shivering grade.

\begin{tabular}{|l|l|l|l|l|}
\hline Shivering grade & $\begin{array}{l}\text { Dexmedetomidine } \\
\text { (Group D) N=40 }\end{array}$ & $\begin{array}{l}\text { Magnesium } \\
\text { sulfate } \\
\text { (Group M) N=40 }\end{array}$ & $\begin{array}{l}\text { Pethidine } \\
\text { (Group p) N=40 }\end{array}$ & p-value \\
\hline Grade -3 & $18(45 \%)$ & $26(65 \%)$ & $27(67.5 \%)$ & 0.067 \\
\hline Grade -4 & $22(55 \%)$ & $14(35 \%)$ & $13(32.5 \%)$ & 0.060 \\
\hline
\end{tabular}

by Chi-square test; *p-value $<0.05 \mathrm{~S}$

\section{Response to anti-shivering drugs:}

As regard to response rate between anti-shivering drugs used in this study that abolished the shivering after the neuraxial block; it showed significant difference between groups as dexmedetomidine group had high response rate $(95 \%)$ followed by pethidine group (80\%) but magnesium sulfate group had the lowest response rate $(60 \%)$. As regard to the time elapsed from drug injection until the response in the present study; it showed no significant change as shown in table (8), the fast response was in dexmedetomidine (6.08 $\mathrm{min}$ ) but the difference is not significant.

Table (8): Comparison between groups according to response rate and its time.

\begin{tabular}{|l|l|l|l|l|}
\hline & $\begin{array}{l}\text { Dexmedetomidine } \\
\text { (Group D) N=40 }\end{array}$ & $\begin{array}{l}\text { Magnesium } \\
\text { sulfate } \\
\text { (Group M) } \\
\mathbf{N = 4 0}\end{array}$ & $\begin{array}{l}\text { Pethidine } \\
\text { (Group p) } \\
\text { N=40 }\end{array}$ & p-value \\
\hline Response rate (\%) & $38(95.0 \%)$ & $24(60.0 \%)^{\mathrm{a}}$ & $32(80.0 \%)^{\mathrm{ab}}$ & $<0.001^{* *}$ \\
\hline $\begin{array}{l}\text { Time elapsed from treatment to } \\
\text { cessation of shivering (minutes) }\end{array}$ & $6.08 \pm 2.16$ & $7.52 \pm 3.91$ & $6.39 \pm 2.37$ & 0.176 \\
\hline
\end{tabular}

p-value $>0.05 \mathrm{NS} ; * *$ p-value $<0.001$ Highly significant

F-ANOVA test; for time elapsed, - Chi-square test: for response rate

(a) Significant change between dexmedetomidine group and magnesium sulphate group.

(b) A significant change between magnesium sulfate group and pethidine.

(ab) A significant change between dexmedetomidine group and pethidine group.

\section{Sedation score (Richmond agitation score)}

This table shows a statistically significant difference between groups according to the sedation score after $10 \mathrm{~min}$. and after $15 \mathrm{~min}$. There was a statistically significant difference according to Richmond agitation score as dexmedetomidine group had more sedative score than other groups as shown in table (9). 
Table (9): Comparison between groups according to sedation score.

\begin{tabular}{|l|l|l|l|l|}
\hline Sedation score & $\begin{array}{l}\text { Dexmedetomidine } \\
\text { (Group D) N=40 }\end{array}$ & $\begin{array}{l}\text { Magnesium sulfate } \\
\text { (Group M) N=40 }\end{array}$ & $\begin{array}{l}\text { Pethidine } \\
\text { (Group p) N=40 }\end{array}$ & p-value \\
\hline Baseline & $-2.02 \pm 0.59$ & $-2.02 \pm 0.59$ & $-2.02 \pm 0.59$ & 0.265 \\
\hline After 5 min. & $-2.16 \pm 0.63$ & $-2.12 \pm 0.62$ & $-2.08 \pm 0.60$ & 0.070 \\
\hline After 10 min. & $-2.38 \pm 0.69$ & $-2.23 \pm 0.65^{\mathrm{a}}$ & $-2.14 \pm 0.62^{\mathrm{ab}}$ & $0.022^{*}$ \\
\hline After 15 min. & $-2.62 \pm 0.76$ & $-2.34 \pm 0.68^{\mathrm{a}}$ & $-2.21 \pm 0.64^{\mathrm{ab}}$ & $0.011^{*}$ \\
\hline
\end{tabular}

p-value $>0.05 \mathrm{NS} ; * *$ p-value $<0.001$ Highly significant

\section{Side effects:}

The current study showed a statistically significant difference between groups as regard side effect. Dexmedetomidine group had more hypotension and bradycardia but magnesium sulfate group had more vomiting as shown in table (10).

Table (10): Comparison between groups according to side effects.

\begin{tabular}{|l|l|l|l|l|}
\hline Side Effect & $\begin{array}{l}\text { Dexmedetomidine } \\
\text { (Group D) N=40 }\end{array}$ & $\begin{array}{l}\text { Magnesium sulfate } \\
(\text { Group M) N=40 }\end{array}$ & $\begin{array}{l}\text { Pethidine } \\
(\text { Group p) N=40 }\end{array}$ & p-value \\
\hline Hypotension & $10(25.0 \%)$ & $0(0.0 \%)^{\mathrm{a}}$ & $0(0.0 \%)^{\mathrm{ab}}$ & $0.002^{*}$ \\
\hline Bradycardia & $8(20.0 \%)$ & $6(15.0 \%)$ & $0(0.0 \%)^{\mathrm{ab}}$ & $0.009^{*}$ \\
\hline Nausea and vomiting & $0(0.0 \%)$ & $8(20.0 \%)^{\mathrm{a}}$ & $0(0.0 \%)^{\mathrm{b}}$ & $0.004^{*}$ \\
\hline
\end{tabular}

p-value $>0.05 \mathrm{NS} ; * *$ p-value $<0.001$ Highly significant

(a) Significant change between dexmedetomidine group and magnesium sulphate group.

(b) A significant change between magnesium sulfate group and pethidine.

(ab) A significant change between dexmedetomidine group and pethidine group.

\section{DISCUSSION}

Shivering is quintessential in our practice. It occurs during both general and spinal anesthesia. Shivering causes an increase in oxygen demand, $\mathrm{CO}_{2}$ production and lactic acidosis. There is also an evident increase in intracranial and intraocular pressures $^{\left({ }^{(6)} \text {. }\right.}$

In the present work, oxygen saturation showed no statistically significant difference between groups after drug administration.

The efficacy of dexmedetomidine in treating and preventing shivering in various clinical scenarios has been demonstrated in previous studies. In this study, all patients treated with dexmedetomidine stopped shivering within average 6 minutes of post-treatment. This result corresponds with that in the study conducted by Easley et al. ${ }^{(6)}$ which showed that 24 children ranging in age from 7-16 years old experienced the cessation of shivering behavior within five minutes following the completion of dexmedetomidine administration. The difference between our study and their study was that ours involved adult patients who experienced shivering post neuraxial anesthesia, while theirs involved children who shivered post general anesthesia. The shivering that occurs during neuraxial anesthesia and general anesthesia share a common pathogenesis. Thus, agents that have proven successful in the treatment of shivering following neuraxial anesthesia might also be useful in the management of shivering during general anesthesia ${ }^{(6)}$.
Dexmedetomidine used to reduce the core temperature and our results correlate with this findings. Studies in healthy volunteers have demonstrated that dexmedetomidine controls shivering by reducing the shivering threshold. Doufas et al. ${ }^{(7)}$ carried out a study in which shivering was induced by infusing cold Ringer's lactate solution $\left(\approx 4^{\circ} \mathrm{C}\right)$ into healthy adult volunteers. The results showed that the shivering threshold was 35.5$36.5^{\circ} \mathrm{C}$ in the group treated with dexmedetomidine. However, in our study, patients did not shiver, even though their temperature was in the range of 36.8$36.9^{\circ} \mathrm{C}$. This might be owing to a difference in the mechanism of shivering under neuraxial anesthesia compared to that induced by cold Ringer's lactate solution ${ }^{(7)}$.

Horn et al. ${ }^{(8)}$ showed that $0.5 \mathrm{mg} / \mathrm{kg}$ bw of pethidine was an effective dose for the treatment of shivering, that is why we administered pethidine $0.5 \mathrm{mg} / \mathrm{kg}$ bw to our patients with grade 3 shivering or higher. In 1999, Wang et al. ${ }^{\left({ }^{9}\right)}$ showed that the response rate with pethidine $(0.4 \mathrm{mg} / \mathrm{kg}$ bw) was $83 \%$ at five minutes and $93 \%$ at 30 minutes. On the other hand, in the study by Bhatnagar $\mathbf{e t}$ al. ${ }^{(\mathbf{1 0})}$ the response rate to pethidine $(0.5 \mathrm{mg} / \mathrm{kg}$ bw) was only $80 \%$. In our study, the response rate with pethidine was $85 \%$, which is comparable with these two studies, although they were performed in post-general anesthesia patients and not in post neuraxial anesthesia patients. The disadvantages of pethidine treatment are the side-effects of nausea, vomiting, sedation and 
respiratory depression, but these did not occur in our patients with the dosage we used ${ }^{(\mathbf{1 1 1})}$.

We have demonstrated that dexmedetomidine, pethidine and magnesium sulfate effectively treat post-neuraxial anesthesia shivering. Dexmedetomidine appears to be more effective than pethidine and magnesium (95\% vs. $85 \%$ vs. $60 \%$, respectively). However, the only statistically significant difference was demonstrated between dexmedetomidine and magnesium sulfate $(\mathrm{p}=$ 0.001), not between dexmedetomidine and pethidine, or pethidine and magnesium sulfate, in reducing postneuraxial anesthesia shivering.

Hypotension and bradycardia are known hemodynamic effects of dexmedetomidine. In our study, five patients developed hypotension and four developed bradycardia after receiving this drug. Nausea was also one of the adverse effects experienced, as shown in previous studies. But, in our study, none of the patients developed nausea or vomiting. All of the patients who received dexmedetomidine were cooperative, oriented, and could respond to commands, and these findings were similar to the results obtained in the study conducted by Elvan $e t$ al. ${ }^{(12)}$.

Dexmedetomidine was found to be effective to combat shivering and can be recommended in the prevention of shivering, keeping in mind hypotension and bradycardia as its side effects.

\section{CONCLUSION}

Based on the results we obtained, we conclude that dexmedetomidine is an effective drug in the prevention of shivering in patients undergoing neuraxial block.

\section{REFERENCES}

1. Miller RD, Eriksson LI, Fleisher LA (2010): Temperature Regulation and Monitoring. In: Sessler
DI, editors. Miller's Anesthesia $7^{\text {th }}$ edition. Philadelphia: Elsevier Churchill Livingstone, 15331552.

2. Simon E (1974): Temperature regulation: the spinal cord as a site of extrahypothalamic thermoregulatory functions. In Reviews of Physiology, Biochemistry and Pharmacology, Springer, Berlin, Heidelberg.

3. Bicer C, Esmaoglu A, Akin A et al. (2006): Dexmedetomidine and meperidine prevent post anaesthetic shivering. Eur J Anaesthsiol., 23:149-53.

4. Bozgeyik S, and Mizrak A (2014): The effects of preemptive tramadol and dexmedetomidine on shivering during arthroscopy. SJA., 8:238-243.

5. Satinoff E (1978): Neural organization and evolution of thermal regulation in mammals. Science, 201(4350):16-22.

6. Easley RB, Brady KM and Tobias JD (2007): Dexmedetomidine for the treatment of postanesthesia shivering in children. Paediatr Anaesth., 17:341-346.

7. Doufas AG, Lin CM, Suleman MI et al. (2003): Dexmedetomidine and meperidine additively reduce the shivering threshold in humans. Stroke. Journal of Cerebral Circulation, 34:1218-1223.

8. Horn EP, Schroeder F, Wilhelm S et al. (1986): Postoperative pain facilitates non-thermoregulatory tremor. Anesthesiology, 91:979-84.

9. Wang JJ, Ho ST, Lee SC et al. (1999): A comparison among naluphine, meperidine and placebo for treating post anaesthetic shivering. Anesth Analg., 88:686-9.

10. Bhatnagar S, Saxena A, Kannan TR et al. (2001): Tramadol for post-operative shivering. A double blinded comparsion with Pethidine. Anesth Intensive Care, 29:149-54.

11. Horn EP, Standl T, Sessler DI et al. (1998): Physostigmine prevents post anesthetic shivering as does meperidine or clonidine. Anesthesiology, 88:10813.

12. Elvan EG, Uzun S, Karabulut E et al. (2008): Dexmedetomidine and postoperative shivering in patients undergoing elective abdominal hysterectomy. Eur J Anaesthesiol., 25:357-64. 